Charles E. Smith MD FRCP. Michael Baxter MD.

Joan C. Bevan MD FFarCs, François Donati PH D MD FRCP, David R. Bevan MB MRCP FFARCS

\title{
Accelerated onset and delayed recovery of d-tubocurarine blockade with pancuronium in infants and children
}

The effect of age on the anset and duration of action of a d-tubocurarine (DTC) neuromuscular blockade with and without pancuronium priming in children was examined. Sixty ASA physical status I or II patients in three age ranges $(0-1$ yr, $1-3$ yr and 3-10 yri were anaesthetized with thiopentone, halothane and nitrous oxide. Each patient received either a single paralyzing dose of DTC $0.4 \mathrm{mg} \cdot \mathrm{kg}^{-1}$, or DTC $0.36 \mathrm{mg} \cdot \mathrm{kg}^{-1}$ preceded three minutes earlier by pancuronium $0.007 \mathrm{mg} \cdot \mathrm{kg}^{-1}$. Evoked farce of contraction of the adductor pollicis was measured using train-of four stimulation applied every $12 \mathrm{sec}$. Time to 90 per cent first twitch depression after a singie dose of DTC increased with increasing age $(r=0.65, p<0.01)$, and was $1.6 \mathrm{~min}(S E M \pm 0.3$ ) in the $0-1$ yr group, $1.9 \pm 0.3 \mathrm{~min}$ $(1-3 \mathrm{yr})$, and $5.2 \pm 1.2 \mathrm{~min}(3-10 \mathrm{yr})$. Time to ten per cent spontaneous recovery after single dose DTC was shorter in older individuals $(r=0.40, p<0.05)$, being $36.4 \pm 5.1 \mathrm{~min}$ in infants $0-1$ yr, $30.6 \pm 4.6$ min $(1-3 \mathrm{yr})$, and $24.0 \pm 2.7 \mathrm{~min}$ $(3-10 y r)$. Priming with pancuronium accelerated the onset significantly in all age groups with 90 per cen $T$, depression occurring at $0.7 \pm 0.1 \mathrm{~min}(0-1 \mathrm{yr}), 0.9 \pm 0.1 \mathrm{~min}(1-3 \mathrm{yr}\rangle$, and $2.1 \pm 0.6 \mathrm{~min}(3-10 \mathrm{yr})$. However, priming delayed recovery, especiaily in infants. Times to ten per cent spontaneous recovery following DTC with pancuronium priming were $71.0 \pm 8.1(0-1 \mathrm{yr}), 42.7 \pm 3.8(1-3 \mathrm{yr})$, and $29.3 \pm 3.9 \mathrm{~min}$ $(3-10$ yr). It is concluded that onset and recovery from a DTC blockade are markedly age-related, and this relationship may be accentuated by pretreatment with pancuronium.

\section{Key words}

ANAESTHESIA: paediatric; NEUROMUSCULAR RELAXANTS: tubocurarine, pancuronium; DRUG INTERACTION: tubocurarine, pancuronium; PHARMACODYNAMICS: priming principle.

From the Departments of Anaesthesia, Montreal Children's Hospital, and McGill University, Montreal, Qucbec.

Address correspondence to: Dr. Charles E. Smith, Department of Anaesthesia, Royal Victoria Hospital, 687 Pine Avenue West, Montreal, Qucbcc, Canada H3A 1 A1.
The pharmacologic response of paediatric patients to nondepolarizing muscle relaxants is controversial. Early reports suggested that neonates required less d-tubocurarine (DTC) than adults when the drug was administered on a mg per $\mathrm{kg}$ basis. ${ }^{1}$ However, Goudsouzian et al ${ }^{2}$ demonstrated that the response of children to DTC is similar over a wide range of ages although there was considerable variability in dosage requirement.

The administration of a subparalyzing dose or priming dose of a nondepolarizing relaxant several minutes before the intubating dose is often employed to accelerate the onset of action. ${ }^{3}$ This acceleration has been demonstrated in adults and children with divided doses ${ }^{3-10}$ or mixtures ${ }^{5.8 .9}$ of relaxants. However, giving pancuronium before DTC in adults, ${ }^{8}$ or administering pancuronium in divided doses in children ${ }^{1 \mathrm{k}}$ did not accelerate onset. Moreover, pancuronium priming significantly prolonged the duration of action of a DTC blockade in adults. ${ }^{8}$

Therefore, this study was designed to examine the effects of age on onset, intensity and duration of a DTC neuromuscular blockade in children. In addition, the effects of pancuronium priming of DTC were evaluated in paediatric patients.

\section{Methods}

Studies were performed after institutional approval in 60 ASA physical status class I or II patients undergoing elective surgical procedures. There were 20 patients in each age range: $0-1$ yr (infants), 1-3 yr (young children), and 3-10 yr (older children).

Patients with hepatic, renal or neuromuscular disease, or those receiving drugs known or suspected to interfere with neuromuscular transmission were excluded. Infants less than six months old were not premedicated. Those older than six months received intramuscular morphine $0.1 \mathrm{mg} \cdot \mathrm{kg}^{-1}$ and atropine $0.01 \mathrm{mg} \cdot \mathrm{kg}^{-1}$ and occasionally rectal pentobarbitone $3 \mathrm{mg} \cdot \mathrm{kg}^{-1}$. Arterial pressure (DINAMAP), heart rate, electrocardiogram and temperature were monitored continuously. After induction of anaesthesia with thiopentone $3-5 \mathrm{mg} \cdot \mathrm{kg}^{-1}$ IV or halo- 
TABLE I Patient data, means \pm SEM (age-months, weight-kg)

\begin{tabular}{lrrrrr}
\hline & \multicolumn{2}{l}{ DTC alone } & & \multicolumn{2}{l}{$\begin{array}{l}\text { DTC with } \\
\text { pancuronium priming }\end{array}$} \\
\cline { 2 - 3 } \cline { 6 - 7 } & Age & Weight & \multicolumn{1}{l}{ Age } & Weight \\
\hline Infants & $6.4 \pm 1.2$ & $8.4 \pm 0.7$ & & $4.4 \pm 0.7$ & $6.6+0.5$ \\
Young children & $23.0 \pm 2.2$ & $11.9+0.8$ & & $\mathbf{2 2 . 9}+1.9$ & $12.8 \pm 0.7$ \\
Older children & $55.2 \pm 4.8$ & $17.7 \pm 0.9$ & & $54.3 \pm 3.6$ & $18.0 \pm 0.9$ \\
\hline
\end{tabular}

$\mathbf{n}=10$ in each group.

thane, the ulnar nerve was stimulated supramaximally with train-of-four impulses $(0.2 \mathrm{~ms}$ duration, $2 \mathrm{~Hz}$ frequency) delivered every 12 sec by a Grass $S 48$ stimulator and SIU5 isolation unit. The force of contraction of the adductor pollicis was measured with a Grass FT03 force displacement transducer, and recorded on a Grass polygraph. After stabilization of twitch recording, one group $(n=30)$ received a paralyzing dose of DTC 0.4 $\mathrm{mg} \cdot \mathrm{kg}^{-1}$ into a fast-running IV, while the other group received DTC $0.36 \mathrm{mg} \cdot \mathrm{kg}^{-1}$ preceded three minutes earlier by pancuronium $0.007 \mathrm{mg} \cdot \mathrm{kg}^{-1}$. Thus, assuming a six to one potency ratio between pancuronium and DTC, ${ }^{12}$ all patients received the equivalent of DTC 0.4 $\mathrm{mg} \cdot \mathrm{kg}^{-1}$ which was expected to produce a block of greater than 95 per cent. ${ }^{2}$ Tracheal intubation was accomplished when 90 per cent first witch depression was reached. Ventilation (with halothane one per cent, nitrous oxide 66 per cent in oxygen) was controlled to maintain normocapnca using the Bain anaesthetic system. ${ }^{13}$ Measurements consisted of: (1) depression of first twitch height $\left(\mathrm{T}_{1}\right)$ every 30 seconds following DTC administration, (2) train-of-four ratio $\left(T_{4} T_{1}\right)$ at 30,50 , and 70 per cent $T_{1}$

TABLE II Onset and recovery times ( $\mathrm{min}$ ) in three paediatric age groups following a paralyzing dose of DTC. Means \pm SEM

\begin{tabular}{lcc}
\hline & DTC alone & $\begin{array}{l}\text { DTC with } \\
\text { pancuronium priming }\end{array}$ \\
\hline Time to $90 \% \mathrm{~T}_{1}$ depression & & \\
$0-1 \mathrm{yr}$ & $1.56 \pm 0.34$ & $0.65 \pm 0.06^{*}$ \\
$1-3 \mathrm{yr}$ & $1.91 \pm 0.34$ & $0.93 \pm 0.13^{*}$ \\
$3-10 \mathrm{yr}$ & $5.20 \pm 1.16$ & $2.10 \pm 0.62^{*}$ \\
& & \\
Time to $10 \% \mathrm{~T}$, recovery & $36.4 \pm 5.1$ & $71.0 \pm 8.1^{*}$ \\
$0-1$ yr & $30.6 \pm 4.6$ & $42.7 \pm 3.8^{*}$ \\
$1-3 \mathrm{yr}$ & $24.0 \pm 2.7$ & $29.3 \pm 3.9^{*}$ \\
$3-10 \mathrm{yr}$ & & \\
& & \\
Maximum $\mathrm{T}_{1}$ depression $(\%)$ & $98.7 \pm 0.7$ & 100.0 \\
$0-1 \mathrm{yr}$ & $98.5 \pm 0.9$ & $99.7 \pm 0.2$ \\
$1-3 \mathrm{yr}$ & $95.7 \pm 1.2$ & $97.7 \pm 1.1$ \\
$3-10 \mathrm{yr}$ & & \\
\hline $\mathrm{n}=10$ in cach group. & & \\
${ }^{\mathrm{p}} \mathrm{p}<0.05$ between groups. &
\end{tabular}

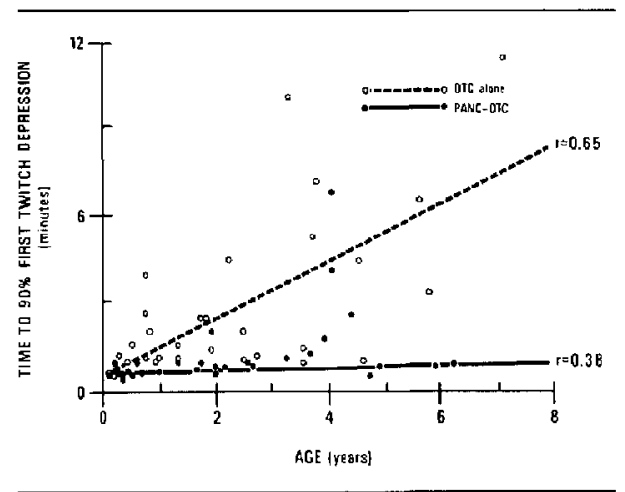

FIGURE ] Relationship between time to 90 per cent first twitch depression and age following d-tubocurarine (DTC) with and without pancuronium (PANC) priming. The linear regression equations are: DTC alone: $y=0.08 \mathrm{X}+0.65, \mathbf{r}=0.65 ;$ PANC-DTC: $y=$ $0.02 X+0.62, r=0.38$.

depression during onset, and (3) time to ten per cent recovery of $T_{1}$. Results were expressed as mean \pm standard error of the mean (SEM) and analyzed by unpaired Student's t test and linear regression. A p value $<0.05$ was considered significant.

\section{Results}

There were no significant differences in age or weight within each subgroup (Table I). The time to 90 per cent $T_{\text {, }}$ depression following the injection of a single dose of DTC was slower in older children $(r=0.65, p<0.01)$ (Figures 1 and 2). Onset times ranges from $1.56 \pm 0.34 \mathrm{~min}$ in the $0-1 \mathrm{yr}$ group to $5.20 \pm 1.16 \mathrm{~min}$ in the $3-10 \mathrm{yr}$ group (Table II). Priming with pancuronium accelerated onset time significantly in all age groups (Table II). In children receiving a priming dose of pancuronium, the onset of blockade was also age-related, although within a narrower time scale $(r=0.38, p<0.05)$ (Figures 1 and 3 ). At 30 per cent first twitch height, patients pretreated with pancuronium exhibited significantly less fade compared

TABLE III Train-of-four ratios (per cent) following DTC in three paediatric age groupes. Mcans \pm SEM

\begin{tabular}{llllllll}
\hline & \multicolumn{2}{l}{ DTC alone } & & \multicolumn{3}{l}{$\begin{array}{l}\text { DTC with } \\
\text { pancuronium priming }\end{array}$} \\
\cline { 2 - 4 } \cline { 5 - 7 } control & $0-1 y r$ & $1-3 y r$ & $3-10 y r$ & & $0-1 y r$ & $1-3 y r$ & $3-10 y r$ \\
\hline $70 \%$ & $74 \pm 2$ & $71 \pm 2$ & $63 \pm 4$ & $71 \pm 3$ & $72 \pm 3$ & $72 \pm 2^{*}$ \\
$50 \%$ & $58 \pm 7$ & $60 \pm 3$ & $47 \pm 4$ & $64 \pm 2$ & $67 \pm 3$ & $62 \pm 3^{*}$ \\
$30 \%$ & $44 \pm 3$ & $43 \pm 3$ & $32 \pm 4$ & $53 \pm 3^{*}$ & $56 \pm 3^{*}$ & $45 \pm 3^{*}$ \\
\hline
\end{tabular}

${ }^{*} \mathrm{p}<0.5$ between groups. 


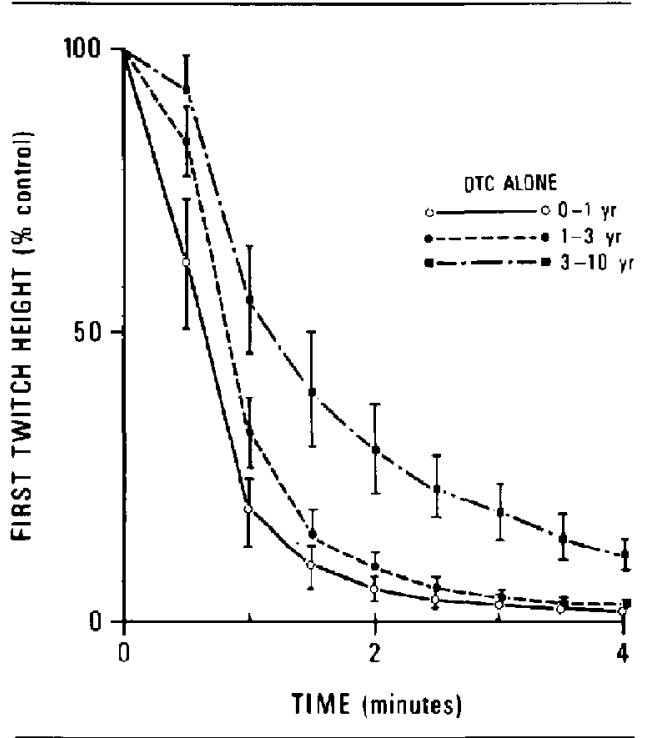

FIGURE 2 First twitch height, cxpressed as a percentage of control with respect to time following a single dose of $\mathrm{d}$-tubocurarine (DTC) in three paediatric age groups.

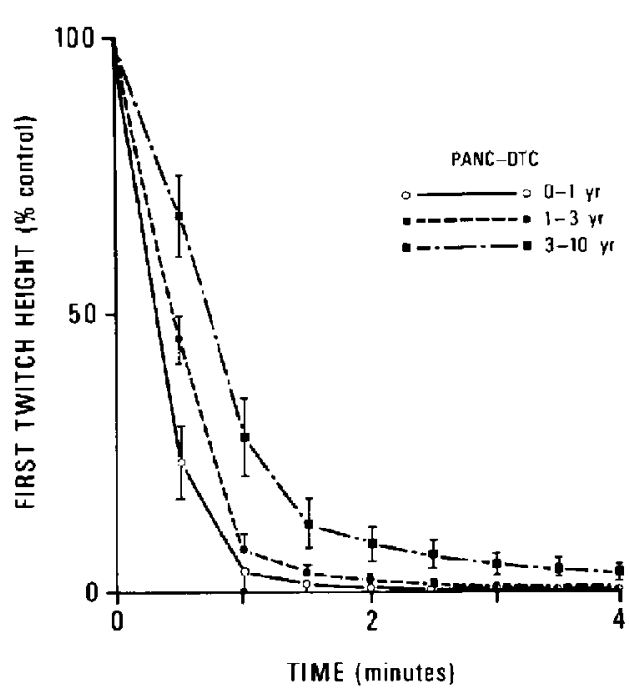

FIGURE 3 First twitch height, expressed as a percentage of control with respect to time after injection of d-tubocurarine (DTC) preceded by a sub-paralyzizg dose of pancuronium (PANC) in three paediatric age groups.

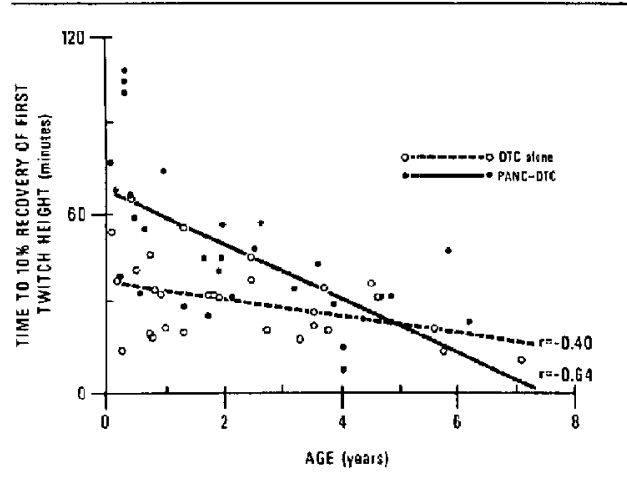

FIGURE 4 Relationship between time to ten per cent recovery and age following d-tubocurarine (DTC) with and without pancuronium (PANC) priming. The linear regression equations are: DTC alone: $y=$ $-0.25 x+37.6, r=-0.40 ;$ PANC-DTC: $y=-0.74 X+69.2$ $\mathrm{r}=-0.64$.

with children receiving single dose DTC (Table III). Recovery was delayed significantly in infants (but not children) primed with pancuronium (Table II). Time to ten per cent $T_{1}$ recovery decreased with increasing age both with $(r=0.639, p<0.01)$ and without $(r=0.404$, $p<0.05)$ priming, indicating a prolonged duration of recovery in younger subjects (Figure 4).

\section{Discussion}

The present study demonstrated that the onset of a DTC neuromuscular blockade was markedly age-rclated whether or not pancuronium priming was utilized. Accelerated onset in younger subjects may be due to a greater cardiac output causing more rapid delivery of the drug to muscles, or increased sensitivity of the infant's neuromuscular junction. Using similar anaesthetic techniques, infants were found to be more sensitive to muscle relaxants than adults (e.g., DTC ${ }^{14}$ atracurium $^{15}$ ). Fisher et al. ${ }^{16}$ demonstrated that the plasma concentration associated with 50 per cent neuromuscular blockade (Cpss 50) was age related: Cpss 50 in neonates was about one-third that noted in adults. This may be due to the incomplete structural and function development of the neuromuscular system during infancy as documented by decreased amplitude of frequency sweep electromyogram at frequencies of 50 to $100 \mathrm{~Hz} .{ }^{17}$ The increased sensitivity of the neonates' junction may be compensated for by the increased volume of distribution of relaxant drugs, so that on a $\mathrm{mg} \cdot \mathrm{kg}^{-1}$ basis, no sensitivity is demonstrated.

The duration of action of neuromuscular blockade with single dose DTC was increased only slightly in infants compared with older children. The rate of disappearance of DTC from blood is characterized by a rapid initial 
decline that is then followed by a slower decay. ${ }^{16}$ Distribution to tissues is the major cause of the initial decline, whereas the slower decay is due to elimination. ${ }^{18}$ Since neonates and infants may exhibit a decreased plasma clearance for DTC, ${ }^{18}$ longer recovery times in infants would be expected. However, the differences in recovery times observed between infants and older children were small. Thus it is possible that the presence of a larger volume of distribution in infants compared with older children accentuates the importance of the distribution phase, making recovery earlier than anticipated.

Pretreatment with pancuronium accelerated the onset of block in all paediatric groups studied, but failed to do so in adults. ${ }^{8}$ This may be due to increased potency of the pancuronium-DTC combination, or increased delivery of this mixture to the neuromuscular junction in children compared with adults.

The administration of a subparalyzing dose of a non-depolarizing relaxant has been shown previously to accelerate the onset of action of the same relaxant in adults ${ }^{3,4,6,7}$ and in children. ${ }^{10}$ This is probably due to the occupation of a certain number of post-junctional receptors without producing paralysis, thereby reducing the margin of safety. ${ }^{19,20}$ When the second larger dose is given, neuromuscular blockade is accelerated because only a small proportion of the total number of receptors need to be occupied to produce paralysis.

Mixtures of two different relaxants may potentiate each other, ${ }^{20,21}$ due to differences in pre- and post-synaptic activity among relaxants, or because of different affinities of relaxants for the two subunits of the acetylcholine receptor. ${ }^{22}$ This synergism may explain the delayed recovery observed following pancuronium priming in infants 0-1 yr, although the younger age of infants who received priming (4.4 vs 6.4 months) might have played a role. Potentiation of DTC by pancuronium priming has also been demonstrated in adult ${ }^{3}{ }^{3}$ where similar doses of the mixture increased time to ten per cent recovery from 39 to $57 \mathrm{~min}$.

More train-of-four fade at the same level of $T_{\text {, }}$ depression was observed when DTC was administered as the sole relaxant compared with pancuronium pretreatment, especially at deeper levels of blockade $\left(T_{1}=\right.$ 30 per cent of control) and in older children. It is known that DTC exhibits more fade than pancuronium because of its greater pre-junctional activity, ${ }^{22}$ and that fade requires time to develop. ${ }^{23}$ Thus it is not surprising that patients receiving DTC as the sole relaxant showed more fade. They required a larger dose of DTC compared with pancuronium pretreated patients ( 0.4 vs $0.36 \mathrm{mg} \cdot \mathrm{kg}^{-1}$ ) and neuromuscular block took longer to develop. This confirms earlier studies in adults, ${ }^{8,20}$ and children. ${ }^{24}$

In paediatric anaesthesia, arterial oxygen tension diminishes rapidly during apnoea, secondary to decreased functional residual capacity relative to tidal volume, and increased oxygen consumption. ${ }^{25}$ In addition, preoxygenation may be difficult in these patients. Therefore, a shorter onset time of relaxants may be of considerable benefit when a rapid-sequence induction and intubation are necessary. Although reductions of onset time by pancuronium priming are smaller in infants as in older children and adults, ${ }^{8}$ even a small decrease might be advantageous because of the reduced reserve in these patients. However, pancuronium priming of DTC may be associated with a prolonged duration of neuromuscular blockade in infants, which can exceed the duration of surgery.

In summary, onset of and recovery from a DTC blockade were significantly age-related. Time to $90 \mathrm{per}$ cent $T_{1}$ depression increased with increasing age, whereas time to ten per cent spontaneous recovery was inversely related to age. Pretreatment with pancuronium accelerated onset in all age groups, but delayed recovery.

\section{References}

1 Long G, Bachman L. Neuromusular blockade by d-tubocurarine in children. Anesthesiology 1967; 28: 723-9.

2 Goudsouzian NG, Donlon JV, Savarese JJ, Ryan JF. Reevaluation of dosage und duration of action of d-tubocurarine in the pediatric age group. Anesthesiology 1975; 43: 416-25.

3 Schwartz $S$, Ilias $W$, Lackner $F$, Mayrhofer $O$, Foldes FF. Rapid tracheal intubation with vecuronium. The priming principle. Anesthesiology 1985; 62: 388-91.

4 Hutron P, Morgan G, El-Hassan K, Black AMS. Speeding the onset of neuromuscular block by alcuronium. $\mathrm{BrJ}$ Anaesth 1983; 55: 918P.

5 Nagashima H, Nguyen HD, Lee S, Kaplan R, Duncalf D, Foldes $F F$. Facilitation of rapid endotracheal intubation with atracurium. Anesthesiology 1984; 61: A289.

6 Gergis SD, Sokole MD, Mehta M, Kemmotsu O, Rudd $G D$. Intubation conditions after atracurium and suxalmethonium. Br J Anaesth 1983; 55: 83S-865.

7 Daherty WG, Breen PJ, Donati F, Bevan DR. Accelerated onset of pancuronium with divided doses. Can Anacsth Soc J 1985; 32: 1-4.

8 Danat F, Walsh CM, Lavelle PA, Bevan DR. Onset of pancuronium and d-tubocurarine blockade with priming. Can Anuesth Soc J 1986; 33: 571-7.

9 Nagashima $H$, Stoll $M$, Nguyen $H$, Duncalf $D$, Foldes $F F$. Surgical relaxation with metocurine-pancuronium combinations. Anesth Analg 1984; 63: 254.

10 Baxter M, Bevan JC, Dortari $F$, Bevan DR. D-tubocurarinc priming in children. Can Anaesth Soc J 1986; 33: S86

11 Bevan JC. Donati F, Bevan DR. Attempled acceleration of the onset of action of pancuronium: effects of divided doses in infants and children. Br J Anawsth 1985; 57: 1204-8. 
12 Goudsouzian $N G$, Ryan $J F$, Savarese JJ. The neuromuscular effects of pancuronium in infants and children. Anesthesiology 1977; 41: 95-8.

13 Rose $D K$ Froese $A B$. The regulation of $\mathrm{PaCO}_{2}$ during controlled ventilation of children with a T-piece. Can Anaesth Soc J 1979; 26: 104-13.

14 Cook $D R$. Muscle relaxants in infants and children. Anesth Analg 60: 1982; 335-43.

15 Brandom $B W$, Woelfel $S K$, Cook $D R$, Fehr BL, Rudd $G D$. Clinical pharmacology of atracurium in infants. Anesth Analg 1984; 63: 309-12.

16 Fisher DM, O'Keefe C, Stanski DR, Cronelly R, Miller $R D$, Gregory $G A$. Pharmacokinetics and pharmacodynamics of d-tubocurarine in infants, children and adults. Anesthesiology 1982; 57: 203-8.

17 Crumrine RS, Yodlowski EH. Assessment of neuromuscular function in infants. Anesthesiology 1982; 54: 29-32.

18 Matteo RS, Lieberman IG, Salanitre E, MCDaniel DD.

Diaz J. Distribution, elimination, and action of d-tubocurarine in neonates, infants, children, and adults. Anesth Analg 1984; 63: 799-804.

19 Paton WDM, Waud DR. The margin of safety of ncurnmuscular transmission. J Physiol 1967; 191: 59-90.

20 Leibowitz PW, Ramsey FM, Savarese JJ, Ali HH. Potentiation of neuromuscular blockade in man produced by combinations of pancuronium and metocurine or pancuronium and d-tubocurarine. Anesth Analg 1980; 59: 604-9.

21 Waud $B E$, Waud $D R$. Interaction among agents that block end-plate depolarization competitively. Anesthesiology 1985; 63; 4-15.

22 Bowman WC. Pre-junctional and post-junctional cholinoceptors at the neuromuscular junction. Anesth Aralg 1980; 59: 935-43.

23 Graham GG, Morris $R, P$ ybus DA, Torda TA, Woodey $R$. Relationship of train-of-four ratio to twitch depression during pançuronium-induced neuromuscular blockade. Anesthesiology 1986; 65: 579-83.

24 Robbins R, Donati F, Bevan DR, Bevan JC. Differentiul effects of myoneural blocking drugs on neuromuscular transmission in infants. Br J Anaesth 1984; 56: 1095-9.

25 Gregory GA. Pediatric anesthesia. In: Miller RD (Ed): Anesthesia 2nd edition. New York, Churchill Livingstone 1986; Chapter 49: 1755-99.

\section{Résumé}

On a examiné l'effet de l'age sur le début et la durée d"action de la d-t thbocurarine (DTC) dans un blocage neuromusculaire avec et sans amorce au pancuronium chez les enfants. Soixante patients, de status physique ASA I ou II, de trois échelles d"âge différentes $(0-1$ an, $3-3$ ans et $3-10$ ans) ont été anesthésiés avec du thiopental de l'halothane et da protoxyde d'azote. Chaque patient a reçu une seule dose paralysante de 0.4 $\mathrm{mg} \cdot \mathrm{kg}^{-1}$ de DTC, ou de $0.36 \mathrm{mg}^{*} \mathrm{~kg}^{-1}$ de DTC précédé de 0.007 $m g \cdot \mathrm{kg}^{-1}$ de pancuronium donné trois min. auparavant. On a mesuré la force de la contraction éraquée de l'adducteter du pouce en utilisant une stimulation train-de-quatre appliquée a toutes les douze secondes. A 90 pour cent de la dépression de la première contraction après une dose untique de DTC, le temps augmentait avec l'age $(r=0.65, p<0.01)$; il étair de $1.6 \mathrm{~min}$ (SEM \pm 0.3 ) chez le groupe de 0-1 an, $1.9 \pm 0.3 \mathrm{~min}$. dans le groupe de $1-3$ ans, et de $5.2 \pm 1.2 \mathrm{~min}$. dans le groupe de $3-10$ ans. A dix pour cemt du rétablissement sponané après une dose unique de DTC le temps était plus court chez les individus plus agés $(r=0.40, p<0.05)$; $i l$ était de 36.4 $\pm 5.1 \mathrm{~min}$, chez les nourrissons de $0-1$ an, $30.6 \pm 4.6 \mathrm{~min}$. chez les enfants de $1-3$ ans. et de $24.0 \pm 2.7$ min. chez les enfants de 3-10 ans. $L$ 'amorce au pancuronium accélérait le début d'action de façon significative dans tous les groupes d'âge avec 90 pour cent de dépression $T_{1}$ se produisant d $0.7 \pm 0.1 \mathrm{~min} .(0-1$ an), $0.9 \pm$ $0.1 \mathrm{~min} .(1-3 \mathrm{ans})$, et $2.1 \pm 0.6 \mathrm{~min}$. $(3-10$ ans $)$. Cependant, Iamorce retardait le rétablissement, particulièrement chez les nourrissons. A dix pour cent du rétablissement spontané à la suite du DTC avec amorce au pancuronium, les temps etaient de $71.0 \pm 8.1(0-1$ an $), 42.7 \pm 3.8(1-3 \mathrm{ans}) . \mathrm{et} 29.3 \pm 3.9 \mathrm{~min}$. (3-10 ans). On conclut que le début d'action et le temps de rétablissement d'un blocage DTC sont reliés à l'age de façon marquée, et cette reiation peut être accentuée par un prétraitement avec du pancuronium 